\title{
THE TARTU RESEARCH GROUP OF PAREMIOLOGY
}

\section{Periodization of the Source History of Estonian Paremiography}

The source history (and historiography as such) of the Estonian proverbs can be divided in three periods and each period in turn can be divided in two sub-periods.

Period 1 (1583-1876). This period is characterized by the same features that characterize the earliest stages of paremiography in Europe and world-wide: publishing exceeds collecting. Little of the folkloristic source material is used, but each publication is an attempt to cover the whole material known to the author. This is the explanation for the great percentage of overlaps in the earliest publications that "begged, borrowed and stole" from each other, as R. Abrahams (1967) has characterized this routine.

Sub-period 1.1. The earliest text known to us that may be a note of an Estonian proverb dates back to 1583. The main sources of this period are early Estonian clerical literature - G. Müller's sermons (q.v. Reiman 1891; Krikmann 1992a), H. Stahl's publications (1632-1638; 1641 and 1649), G. Saleman's Etzliche Gebete (1655), etc., as well as grammars and glossaries of the Estonian language (both published and manuscript) written by German ministers for other German ministers - H. Stahl (1637), J. Gutslaff (1648), H. Göseken (1660), J. Hornung (1693), S. H. Vestring (1720s?), J. Ch. Clare (1730s). The last and greatest source of the sub-period is A. Thor Helle's grammar (1732) which includes ca. 550 proverbs and sayings all in all.

Sub-period 1.2. A. W. Hupel's grammar (1780, 2nd edition 1818) mainly repeats Helle's paremic material. Proverbs were included in the first didactically inclined books for the Estonian masses - Fr. G. Arvelius (1782 and 1787) and Fr. W. Willmann (1782), as well as in the earliest Estonian calendars, journals, school books. The catchword of the sub-period is Estophilic hobby of philology, mainly pursued in learned societies (especially in the Gelehrte Estnische Gesellschaft and later in the Estonian Writers' Society) which have produced new original material in the field of sayings, e.g. J. Fr. Heller's manuscript Estonian-German dictionary in the Võru dialect (1830s?), J. H. Rosenplänter's Beiträge (1813-1832) and, especially, F. J. Wiedemann's Estonian-German dictionary (1869) and his ethnographic work about the "internal and external life" of the Estonians (1876). The latter contains about 4,500 texts of proverbs and is the most comprehensive publication of the Estonian proverbs over the following 80 years.

Period 2 (1876-1964). The general characteristic of the period is that collection exceeds publication: this is the period when the greater part of the manuscript archive funds of the Estonian folklore are compiled.

Sub-period 2.1 covers the interval from Wiedemann's book approximately to the foundation of the Estonian Folklore Archives (1927). The general background of that period is the establishment of tremendous folklore funds by J. Hurt and M.\&nbspJ.\&nbspEisen. These funds contain mainly the material sent by local correspondents. The total amount of proverbs and sayings in these funds is ca. 100,000 texts, but Hurt could publish hardly anything from the expressions of his collection 
and Eisen's books of proverbs are published only at the threshold of World War I (1913a; 1914a). However, the last decade of the 19th century saw the publication of a great number of smaller series of proverbs and individual texts in various school and children's books, calendars, journals and newspapers.

\section{Notes}

Otto Moll's (1958:461) reference to Max Hurt's 1893 publication (see reference No. 7214) is based on a sort of mystification, we think.

Sub-period 2.2. The Estonian Folklore Archives (in the Soviet period reorganized as the Folklore Department of the Estonian Literary Museum) sets in a new level of quality of folklore collection: scholars, professional folklore specialists and philologists start to participate systematically in collection work, special bulletins start to be published that offer questionnaires and methodical instructions for local correspondents. The Estonian Language Archives are established. When compared with the vast amount of archive materials, the fact that the publication of proverbs constantly lags behind becomes even more conspicuous - with the exception of the second edition of Eisen's work (1929), only one special book on proverbs is published at that subperiod - E.\&nbspNormann's selection (1955). This includes ca. 3,600 thematically arranged texts. The material comes from manuscript folklore funds and earlier publications; the introduction gives a survey of the themes of Estonian proverbs, their relations with other genres of folklore and literature, tropes, structure and sound imagery as well as source history. A remarkable amount of genuine archive material is included in school textbooks.

Period 3 (1964 to date). Publications issued within the Baltic-Finnic Proverb project balance the collection and publication of proverbs; simultaneously, noteworthy paremiological research work is started.

Sub-period 3.1 (1964-1975) - the manuscript of the scientific edition of Estonian proverbs is completed.

Sub-period 3.2 (1975-1992) - the "Baltic-Finnic" stage when, under V.\&nbspMälk's a.o. editing, scientific publications of Vote, Livonian and Vepsian proverbs $(1977 ; 1981 ; 1992)$ and a comparative publication of Baltic-Finnic proverbs Proverbia Septentrionalia (1985) are issued, as well as all volumes of Eesti vanasõnad (Estonian Proverbs) (1980-1988) and Vanasõnaraamat (Proverb Book), a thematically arranged popular publication (1984). 


\section{Baltic-Finnic Proverb Project}

\subsection{Three significant paremiological undertakings by Matti Kuusi}

In the early 1960s or even before that, Matti Kuusi contemplated three significant ideas.

The first one: The idea to establish an international journal of paremiology. The plan was carried out in 1965 as Proverbium started to be published in Helsinki by the Finnish Literature Society. It was an information bulletin according to its title, but actually a journal that published 25 issues within 10 years, as a result of Kuusi's selfless efforts and in spite of a constant shortage of money. In 1980, Vilmos Voigt made an attempt to re-establish the international forum for paremiology with Proverbium Paratum, which saw 3 issues within the first 3 years (1980-1982) and a fourth one within the following 7 years - A. Tóthné-Litovkina's (1988?) study on Hungarian and Russian parallel proverbs. The second resuscitation of Proverbium took place in 1984 when a yearbook started to be published under the same title in the United States, edited by Wolfgang Mieder. The American Proverbium has seen - again, in spite of its financial difficulties - 10 issues within the past 10 years, and its circle of correspondents has expanded both personally and geographically. Outside the Proverbium, Mieder's enthusiasm and productivity have also been positively overwhelming.

The second idea: to compile an international typological index of proverbs (on the analogue of Aarne-Thompson's index of folk tales). In the 1960s and 70s, Kuusi compiled a file of parallels which was based on a vast amount of material world-wide and published some abstracts and generalizations from it, partly in his Proverbium (q.v. Kuusi 1970; 1972). Later the file was transformed into a computer data base. The register has not yet been published as a book, but last year, Kuusi and his daughter issued a thick volume of proverbs of the peoples of the world, translated into Finnish and in the original semantic rubrication (Kuusi and Lauhakangas 1993).

The third idea: to issue a comparative publication of proverbs of North European peoples. This idea is most closely connected with our subject and therefore we are going to take a closer look at its course of realization.

\subsection{Estonians set off to the Baltic Sea in a nutshell}

The first stage of the North European publication was planned by Kuusi to contain common proverbs of Baltic-Finnic peoples.

Since the Estonian paremic archive material is the second largest of the Baltic-Finnic peoples (next only to the Finnish one), in autumn 1962 Kuusi suggested co-operation with the relevant Estonian institutions, and after a year an official contract was signed between the Finnish Literature Society and the Academy of Sciences of the Estonian SSR. It was the task of the Estonians to prepare a scientific edition of Estonian proverbs as well as to publish Vote, Livonian and Vepsian proverbs. A working group was formed which included (in order of seniority) Erna Normann (leader), Veera Pino, Ingrid Sarv and Arvo Krikmann. Work was started in January 1964.

Soon it became clear that participation in Kuusi's project was quite an adventure for Estonians, because the whole thing included serious controversies between the opportunities and aspirations on one hand and duties on the other. 
1. The Estonian publication was expected to be completed in two years.

2. According to Kuusi's axiomatic prescriptions, the material was to be arranged according to type articles (entries, typological units), which presupposed that all texts representing a type of proverb should be assembled in a file.

3. As was Kuusi's idea at that time, a type article ought to be a semi-investigational product on a carcass of a type monograph, offering a remarkable amount of elements of redaction analysis, etc.

4. The proverb files of the Literary Museum then included about 70,000 texts with a preliminary typological arrangement and about 60,000 ones with no arrangement whatsoever. The file included hardly any texts from the folklore collections of other institutions or newer linguistic collections. The material representing the so-called poetical folk calendar was very poorly copied into the proverb files. Only the presumably most important ones were copied from printed sources and there were many gaps.

5. Nobody had considerable preliminary knowledge about proverbs, except Normann, and not one of us had a clear vision of the technical parameters of what we set out to do: what is the principle of choice of the material to be published, how is it arranged within the type article and how are the articles sorted; what is the structure of a type article (texts, commentaries, etc.), how extensive is the whole work to be, etc.

Unfortunately (or, as an afterthought, rather fortunately) the majority of participants had no idea of it at that time and those who had were so much tempted to participate in a prestigious international project that they simply could not resist it. As they say, the air was teeming with sinister expectations.

\subsection{Unexpected things that were expected}

The first and most serious problem that we encountered and that we had to face until the end of our work was the amount of non-authentic archive texts. If somebody undertakes to compile a publication of Estonian proverbs, the texts contained in it should be recordings of Estonian proverbs - i.e. everything that is not "Estonian" or "proverb" or "recording" should be excluded. The two pivotal characteristics of non-authenticity in our empirical experience turned out to be doubles and nontraditionality - i.e. a text is not an immediate extract of tradition but a copy or redaction of an earlier text, and/or the text does not represent (Estonian) folklore but the recorder's own aphoristic creation, deliberate redaction of the original folklore material, translation of a proverb of another nation which is not a folklore borrowing, etc.

By now it is known that ca. $48 \%$ of the texts that made up the source material of Eesti vanasonad (henceforward: EP) do not correspond to one or more of the above-mentioned criteria and have to be rejected. (The relationship in absolute figures is ca. 78,000/162,000). When starting the work, none of us could imagine that the percentage of non-authentic material was so high, and the idea of it being so developed gradually, because our files only had an imperfect collection of copies of printed texts and the typological arrangement of the material was not finished - i.e. it was impossible to trace copyings from a printed source to a manuscript or from one manuscript to another. And even when this idea had become quite clear, the preventive measures we took were not radical at the beginning, as the whole work was carried out in a hysterical atmosphere of hurry.

But inevitably there came a moment when it was clear to us that we were facing an enormous dilemma: 
either to prepare a simulative object for the prescribed deadline which, though called a scientific publication, would actually have very little scientific value, and which nonetheless would require much time and energy and burden us with life-long pangs of consciousness and a feeling of shame;

or to try to find and copy as nearly all as possible printed texts (potential sources of copies) containing proverbs, to establish special "intelligence files" for observing corrupt borrowing relations and carry out a full-scale authenticity check with scrupulous precision, ignoring all deadlines and taking the risk of the Estonians being excluded from the project because of their permanent state of grogginess, with the following personal sanctions.

\subsection{Board three inches above water, land in sight}

Fortunately, we were brave enough to take the latter alternative and, again fortunately, this turned out to be feasible. The deadlines were not prolonged all at once and radically, but gradually and repeatedly. Administrative measures also did not fail to appear. In autumn 1965, Erna Normann was degraded into an ordinary member of the group and the leader's role was given to Herbert Tampere, an outstanding specialist in folk music and runo songs and the long-standing director of the Folklore Department of the Literary Museum. However, loaded with many tasks and suffering from a severe heart disease, Tampere soon relinquished the actual supervision of the work. There were no disastrous consequences, as by that time the work group was quite experienced and needed no supervision.

The non-authenticity of texts was the worst of all time consumers that we had to face, that caused serious debates and required the revision of already completed work; it was not the only one, however. Another such thing was the presentation of texts and the degree of "writing them out" in a type article, a third one the delimitation of typological units and the vagueness of the limits of types at places. All this has been described thoroughly enough in the introductions of volumes I, V:1 and $\mathrm{V}: 2$ of EP.

Till the present day, we do not know exactly how adequate was the current idea that Matti Kuusi had about this agony that the Estonian publication suffered from in the mid-1960s, and its gradual recovery in the following years, how were these developments presented to him and how he estimated our prospects at this or that moment. Anyway, we heard not even the remotest repercussions of him planning to freeze or cancel the project.

One of the latest and greatest crises came to the surface at the very end of the $1960 \mathrm{~s}$. By that time, Normann was almost incapable to work, Pino had got married and moved to Tallinn, Krikmann had started his post-graduate studies. From the whole original team, Ingrid Sarv was the only one to remain and she brought two young people into the group, namely Rein Saukas who had just graduated from the university (1970) and Anne Hussar (1971), who are the most prolific members of the group at present. The work was carried on and in 1973, Arvo Krikmann who had finished his dissertation again joined in. In 1975, the manuscript of the main volumes of EP was finally completed and from 1980 on it was issued volume by volume.

\subsection{How good a publication is Estonian Proverbs?}

By now, EP has received mostly positive and appreciative assessment (e.g. Kuusi 1980 and 1990, Laukkanen 1982, a.o., although see also, Salo 1980). Probably, on the background of paremiological publications in general it does look good, regardless of its technical design - already 
the archive material as such on which it is based is awesome, being perhaps only a degree less than the corresponding Finnish one, where the sananparsi genre is represented by the greatest number of texts in the world - over 2 millions.

In an ideal case, the scientific genre publication should convey all the information stored in the source material. EP comes so close to that ideal that its shortcomings are quite grievous indeed. EP quotes all the "real variants" of each proverb, i.e. formulation variants with even the slightest differences, only the dialectal differences in the same word stems are not considered differences. Every such variant is accompanied by abbreviations of the names of the parishes where the real recordings come from, but you can never know how many authentic texts come from each parish, and in case there are many places where these have been recorded (and a study of their spread might be of particular interest), generalizations have often been made in order to spare room, such as "Virumaa", "Võru-Setu", "known all over the mainland but not on the isles", etc. Names of the recorders are given only exceptionally, dates are omitted altogether. Bringing the information capacity of EP to the ideal degree would have been technically quite easy, but the work had to be finished in a hurry in the first half of the 1970s, and what's more, the manuscript had grown to 2,700 pages anyway, so that even the smallest changes would have required an enormous amount of time and expanded the work even more, and yet 30,000 of the newest recordings would have to be left out. In fact, in the final stage of work nobody would even propose seriously to introduce such improvements.

In order to make each authentic text in the archives suitable for being quoted individually, the following changes should have been introduced:

1) To check every formulation variant $(W)$, whether it has one or more corresponding dialectal variants $(D)$ : if more than one, every $D$ should be written down separately;

2 ) To check if each $D$ has one or more real places of origin $(G)$ : if more, every $G$ should be listed individually;

3) To check every $D \& G$, whether the combination has been recorded by one or more persons $(P)$; if more, each $P$ should be listed individually;

4) To check every $D \& G \& P$, whether the recordings are dated with one or more years $(Y)$ : if more, each $Y$ should be marked separately;

5) To check every $D \& G \& P \& Y$ whether it is represented by one or more real texts $(T)$ : if more, then the number of texts should be marked after the corresponding combination;

6) To sum up the numbers of $T$-s (and doublets) under each $M$ like it has been done on the level of $W$-s.

And, of course, EP contains no proverbs used in the Estonian-language fiction and up to this day we have no clear idea of what this material looks like, how much there is of it, to what extent the authors have operated with their own immediate knowledge or used additional sources, etc.

EP slipped through the censorship of ideology bosses and Glavlit, losing only a few feathers. Only a single text was removed - I'd rather be eaten by the dogs of my own country than by the wolves of Russia from Type 11230. We had to make some changes in the introduction, though. For example, in the original variant we were said to have attached too much importance to Matti Kuusi's role in launching the EP, and in the printed version it depends rather on the inherent needs of the Estonian folklore studies. Also, we had to add the Soviet period to the periodization of the source history of Estonian proverbs when the study and publication of proverbs was to flourish like never before. At 
that time this period was indispensably and automatically added to every historiography, and a Westerner could only vaguely and theoretically grasp the shock of associations created by a scene that one of us had a chance to witness. In autumn 1961, a Tartu student chap takes a booklet on medicine lying on his night table, reads on the first page: "Dysentery has been known to mankind for thousands of years...", and adds, "...but it was only after the October Revolution that it really began to thrive."

\subsection{Vaina Mälk and others}

EP does not offer any parallels from other peoples, because as we knew, it was a preliminary work for a special publication of parallels and this would have brought about unnecessary duplication. However, in the late 1960s when the large publication of Karelian proverbs (Miettinen and Leino 1971) and the publication of the best known Finnish proverbs (Laukkanen and Hakamies 1978) as well as those of Vote, Livonian and Vepsian proverbs were not yet issued, the Tartu work group created a manual file of Estonian-Finnish parallel proverbs on the basis of Estonian archive materials and the best known Finnish printed sources (Koskimies 1906; Vaasan Jaakko 1920; Nirvi and Hakulinen 1948, with the preceding district selections (Posti 1936; Luukko 1938; Kaukamaa and Valonen 1939; Laiho 1941; Vesikansa 1941; Saarto 1945); Kuusi 1953). On a latter stage of the project, this preliminary work made our work on finding Finnish-Estonian parallels much easier.

The publication of the proverbs of "small" Baltic-Finnic nations was to be Vaina Mälk's task. This work lasted for 20 years or so, and during these years, Mälk and her colleagues, specialists in Finno-Ugrian studies (T.-R. Viitso, A. Kährik, E. Adler, M. Joalaid, a. o.) published high-level and comprehensive works on Vote, Livonian and Vepsian proverbs (Mälk 1977; Mälk et al. 1981; Mälk et al. 1992). Methodically and technically these publications are congenial with each other as well as with EP. As for the amount of material, each of them is larger than the preceding one(s): the Vote publication contains 728 types and 1,637 individual texts, the Livonian one, respectively, 1,088 and 2,045, the Vepsian one 1,679 and 4,937. As in EP, the material is presented according to the types, but unlike in EP, at the end of every type article there are parallels from the Baltic-Finnic and other peoples with whom that particular nation has had the closest ethnic, historical and linguistic contacts, and in all cases an Estonian parallel if there has been one.

All Mälk's publications begin with a comprehensive introduction in Estonian, with in toto translations into Russian and German. These include the main historical details of the given people and throw light on the history of their folklore collections; the most important paremical sources are named and characterized. Numerical data of the material is added: the general capacity of the fund of proverbs and frequency distribution of types according to their degrees of productivity (amount of texts) and places of origin. The most outstanding native informants and/or collectors are mentioned. In every introduction, a separate subdivision is formed by a survey of the relevant sphere of influence of that particular folklore: the amount of parallel proverbs with other BalticFinnic and other nations; analysis of the Russian-Vote, Russian-Vepsian and Latvian-Livonian parallels, etc.

At the end of each publication there are several registers a. o. useful additional information. In extenso:

1) List of sources with abbreviations;

2) List of the relevant villages and informants with abbreviations;

3) Ethno-geographic divisions of the areas of habitation of other peoples represented in the publication; 
4) Abbreviations of the biblical equivalents;

5) Lists of calendar festivals of the relevant peoples;

6) Lists of the combinations of ethnic groups that appear in the parallels, with type numbers representing each combination;

7) Translations of the primary texts of all types of proverbs into German;

8) A comprehensive register of words;

9) A number of maps, incl. maps of distribution of the proverbs that are most significant from the point of view of the Baltic-Finnic folklore relations.

\subsection{Meetings with Finns}

The central Estonian folklore archives are situated in the Literary Museum, and the Literary Museum is situated in Tartu. Thus, Tartu, alongside with Helsinki, should have been a natural meeting and working place of the participants of the Baltic-Finnic project. However, Tartu was the location of not only the Literary Museum, but also of the then very important Russian military airfield and therefore, it was a forbidden city for foreigners. Our actual meeting places were Tallinn and Helsinki, especially Tallinn, because for Finns to come to Tallinn was just a matter of undertaking, whereas it was very unusual and troublesome for an Estonian to get to Helsinki.

In the late 1960s or early 1970s Kuusi obviously started to believe that the Estonian publication was finally getting ready despite everything and he began to think more seriously about the preparations of the actual Baltic-Finnic comparative publication. In 1970, the International Finno-Ugric Congress took place in Tallinn which included also a symposium on paremiology where the BalticFinnic project was one of the main issues under discussion. In 1971, a joint symposium of Finnish and Estonian philologists took place in Helsinki, and in 1973 an analogical one was organized in Tallinn, and the publication of proverbs was discussed on both of them. In spring 1975 when the manuscripts of the Estonian and Vote publications were practically finished and the Livonian one began to take shape, Kuusi came to Tallinn and organized a week of workshops: he drew up several provisory lists and concordances of Baltic-Finnic parallels, discussed the issues of general principles, volume, typologies, etc., with Estonian researchers. There were other, brief meetings in the following years.

The immediate work on the final product of the Baltic-Finnic proverbs, which later on was named Proverbia Septentrionalia (henceforward: PS), started in January 1979, as the authors of the present article were not only allowed on an unbelievably long research visit (20 days) to Helsinki, but also a permit to take along a whole heap of excerpts from the yet unpublished manuscript of EP. On this meeting, the last unsolved problem was cleared up, namely that which concerned the profile and structure of a type article. Kuusi found that a type article should include a sufficient amount of elements of redaction analysis, hypotheses about borrowing, a. o. semimanufactured research products. Laukkanen together with the two of us opposed to this idea, saying that first, this was no business of the publication, second, this could only be done in a few individual cases, as the majority of types were represented by scarce material, and third, this would slow down the pace of work. Vox populi prevailed, it was agreed that an article should look like it does in PS at present, and the actual work on the compilation of sample articles was started.

From then on, hard work continued on both sides of the Gulf of Finland, and there were numerous academic meetings, which in the early 1980s were mostly held in Tallinn. From the Finnish side, besides Kuusi, Kari Laukkanen was also hardly ever absent, participants on the Estonian side were 
Sarv, Krikmann, Mälk, Joalaid, etc. Between the meetings, there was a constant dialogue and exchange of information by mail. It was a pleasant, though routine and technical stage of work.

From that period, we would like to mention some incidents in connection with Kuusi's facial expressions - he who knows them, will understand. One morning, after he came from the hotel through "Orwell's world" to the Institute of Language and Literature, Kuusi wondered: "I wear the most ordinary grey jacket, the most ordinary grey trousers and the most ordinary old briefcase why are they always staring at me in the streets?" Evidently, Kuusi also had to thank his Kalevalaexpression for what was always done to him at the customs check. While the daily working routine of the Tallinn Harbour customs at that time was to dismantle every traveller to molecules, Kuusi was mostly disassembled to atoms and reassembling took some time. We, his seeing-off party, spontaneously lifted a sigh of relief when he strode to the ship half an hour after all the others were gone, in aristocratic solitariness, bearing the same Kalevala-expression on his face and carrying the pile of atoms in his lap.

\subsection{Three more statements on Proverbia Septentrionalia}

PS was published as the 236th issue of the quite popular FFC series and the readers of Proverbium got a survey of it by Wolfgang Mieder (1986) that was so comprehensive that it is not necessary to repeat it here. Only some of the details will be stressed.

1. PS includes merely 900 types of proverbs, but as these are the most productive among the BalticFinnic ones, the amount of source texts representing them is huge: ca. 83,000 from Finland, 47,000 from Estonia, 10,500 from Karelia, 900-1,700 from each of the rest.

2. As was mentioned by Mieder, PS is oriented on the principle of frequency in various senses of the word - in the choice and arrangement of the material as well as in this sense that the familiarity of each proverb among each nation has been measured by the number of the respective authentic source texts.

3. The so-called analytical table (PS, pp. 42-76) offers really abundant information about the material included in the publication in a very concise form (and, perhaps, too much so).

Thanks to all that, the book enables to draw up all sorts of statistical overviews and to observe even visually some interesting effects which come up while proceeding from the more productive part to the less productive one, e.g. the decreasing number of non-Baltic-Finnic parallels in the analytical table.

One can give the following example.

Trying to evaluate the percentage of borrowed proverbs in the Finnish folklore on the basis of A. A. Koskenjaakko's works, Matti Kuusi (1954:55) has made the following observations: "The better known Finnish proverbs are mostly spread all over Europe. It is indisputable that these include the most majestic ones of popular aphoristics, real pearls that are never dimmed." This observation as well as several analogous ones would allow us to come up with a generalized hypothesis such as: The more peoples know an expression (or a folkloristic item in general), the more productive (popular, frequent in the archive material) it is among each nation who knows it; or, to put it briefly, the "horizontal" and "vertical" dimensions of folkloristic productivity are in positive correlation with each other. Unfortunately, as far as we know, nobody has come up with such a hypothesis, but if somebody had, PS material would give good arguments in favour of it on various levels, e.g. see the following numbers: 
1)

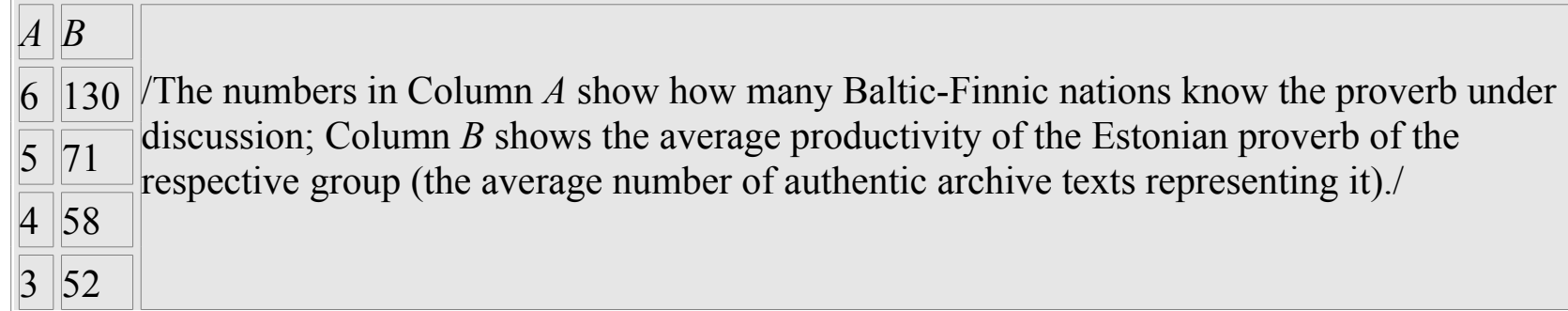

2)

\begin{tabular}{|l|l|l|l|l|l|l|l|}
\hline$A \backslash B$ & 4 & 3 & 2 & 1 & 0 & $-^{(A)}$ & ${ }^{B(A)}$ \\
\hline 6 & 39 & 8 & 4 & 1 & - & 52 & 3.63 \\
\hline 5 & 56 & 23 & 27 & 11 & 7 & 124 & 2.89 \\
\hline 4 & 61 & 35 & 39 & 31 & 21 & 187 & 2.45 \\
\hline 3 & 37 & 37 & 43 & 57 & 83 & 257 & 1.56 \\
\hline$(B)$ & 193 & 103 & 113 & 100 & 111 & 620 & \\
\hline
\end{tabular}

I $A$ shows, as previously, the number of Baltic-Finnic nations who know the proverb; $B$ - the number of non-Baltic-Finnic neighbours knowing the same proverb; the numbers in the table cells show the number of proverb types corresponding to each combination of $A$ and $B$ in PS; the column $B(A)$ gives the (weighted) average $B$ corresponding to each rank of $A$.

\subsection{What next?}

PS has only one great disadvantage - it does not contain all the Baltic-Finnic parallel proverbs by far, but only the most stereotypical, most "common-North-European" ones, leaving out the less productive layers, which, however, would be particularly interesting for a purely Baltic-Finnic field of studies.

Kuusi had decided to terminate his participation in the Baltic-Finnic publication after PS, and so he did. At first, other participants had a childish conviction that in spite of that they would be able to carry on their work, and they sent memos to the respective institutes of both countries. But due to a change of priorities in the Finnish folklore studies, the whole thing was slowed down and soon Kari Laukkanen who had been one of the leading figures of the project together with Kuusi resigned his post at the Folklore Archive of the Finnish Literary Society. In the late 1980s, the Estonian working group also shifted their focus of attention (to riddles) and the prospects of going on with the project became purely theoretical.

Such a course of anti-events was particularly sad for the Estonian side, as it was us who had done considerably more preparatory work than was actually used in PS: a dozen volumes of publications, a great number of parallels fixed in Mälk's works, files of Estonian-Finnish and Estonian-Russian proverb parallels, etc.

Moreover, the extinction of the project would be senselessly tragic because the general principles of the Baltic-Finnic publication, the technical pattern of type articles, the system of registers, a. 0. 
additional information (incl. the analytical table) were clearly and definitely elaborated and went through practical tests in PS and if the work were to be continued, it would be very easy for us to follow these patterns.

Luckily, in autumn 1993, consultations about continuing the work on the Baltic-Finnic publication were revived; the starting dialogue was held between Pentti Leino and Arvo Krikmann. In April 1994, the Estonian research group of paremiology got very welcome financial support from Open Estonia Foundation to go on with the project of Baltic-Finnic proverbs. With the existing information, familiar technical routine and the received financial support, the Estonian research group will be able to do much of the required preliminary work of the following volumes of the Baltic-Finnic publication on their own within the next few years.

Let us remember that the Baltic-Finnic project itself was meant to be the first stage of the North European hyper-project, and in fact, within the past few decades people have been working in this direction not only in Finland and Estonia, but also in Latvia and Lithuania (q.v. Kokare 1967; 1980; 1988, and especially Grigas 1987). It would be sad if the outstanding publications of the Baltians would remain "things in themselves" that would not flow into a greater stream and, through that, into the ocean.

\section{Study of Proverbs}

Joining in the Baltic-Finnic Proverbs project meant, among other things, a beginning of the Estonian paremiology in the sense of scientific research work.

Owing to the preparatory work of the Estonian Proverbs (arrangement of the material in the archives, authenticity check, volume of registers, etc.), proverbs are actually the only genre of Estonian folklore which can be evaluated quantitatively on a satisfactory level and which allows statistical analysis on several plains. So far, such observations have been made mainly about the geographic spread of proverbs. A method that uses some elements of linear regression analysis has been developed for the evaluation of the density of connection between parishes and other geographical units: the method is oriented to the relations of the stereotype/unique of the choice of material (Krikmann 1979); relying on this method, an attempt has been made to figure out the Estonian "proverb regions" (Krikmann 1980); there have been attempts to find reflections of some historical or ethnographic events in the geographic distribution of proverbs (Krikmann 1978a), etc. PS itself is also well equipped with frequency information, which has offered a ground for provisory calculations for the evaluation of the density of connection between the Baltic-Finnic peoples and between the Baltic-Finnic and non-Baltic-Finnic ones (Krikmann 1985/1987). As for other kinds of statistical analyses, one may point out the interim report of G. Permjakov's paremiosociological experiments (Krikmann 1986a; see also Permjakov 1971; 1988; cf. Grzybek and Chlosta 1993).

Another field of investigation has been various aspects of the content of proverbs. The method used in Soviet folklore studies of examining the world outlook of the proverbs has been criticized (Krikmann 1975), various issues concerning the trope semantics of proverbs and levels of modality (Krikmann 1974/1984; 1974/1985; 1978b; 1984/1988; 1992b; 1994), logical structure (Krikmann 1984/1987), semantic classifications of proverbs (Krikmann 1974; 1975; 1984), etc., have been dealt with. Vanasõnaraamat (Hussar, Krikmann and Sarv 1984) as a whole is the first more or less serious attempt of actual classification of Estonian proverbs according to their contents.

Until the present day, the source history of Estonian proverbs and popular phrases a.o. historiographical material has found only occasional treatment, mainly before the formation of the 
research group for paremiology (Laugaste 1955; Normann 1959; 1961; Sarv 1964a; Krikmann $1986 b ; 1992$ a).

Ingrid Sarv has completed a monograph (which has not been published yet), which deals with proper names and appellatives in Estonian proverbs and turns of speech.

\section{Work on Riddles}

In the late 1980s when the volumes of Estonian Proverbs were completely published and the prospects of continuing the work on the Baltic-Finnic publication were still vague, the research group of paremiology tackled another genre of Estonian folklore - the riddles.

Estonian folklore archives do not contain quite as many riddles as there are proverbs: while our general files of proverbs include archive and printed texts, 200,000 all in all, the file of riddles counts about 150,000. In \&nbspthe earlier stage of the collection and publication of Estonian riddles, an especially important role was played by M. J. Eisen. The editions of his two books of riddles (Eisen $1890 ; 1913 b ; 1914 b$ ) are the only noteworthy publications of Estonian riddles until the present day.

We saw our first and foremost goal in the preparation of a scientific publication analogical with that of proverbs and belonging to the series Monumenta Estoniae Antiquae. The systematic work started in 1990 and the deadline is the year 2000. The general disposition and the whole course of work has differed radically from these of the early years of the proverb project. The nucleus of the team has been the same, i.e. we have the whole experience gained during the work on the proverb project (painful, but effective) at our disposal. We knew from the beginning which stages of work we had to go through and approximately how much time they would require. The time required for completing the work has been spared. The basic files were arranged typologically by Erna Normann in the 1930s and 40s (in most cases with the precision of a type, in some cases that of a redaction) and related types have been equipped with a very good system of cross reference. There is no time gap between the file and the original collection, the original texts have been copied "up to date". By now the majority of the material has been arranged within types (on the level of variability) and a detailed authenticity control is under process (the authenticity niveau of the texts being roughly equal to that of the proverbs). The work is progressing briskly and without any impediments.

In spring 1992 the folklorists of the Literary Museum and the Institute of Estonian Language organized a competition of collecting contemporary schoolchildren's folklore in Estonian schools; this action brought a vast amount (round 27,000 pages) of new material into the archives, including about 3,200 texts of the so-called "ordinary" riddles and approximately 25,000 texts from the "periphery" of riddles (conundrums, puzzles, a. o. "tricky" questions and tasks, rebuses, etc.). This material offers us interesting information about the contemporary status of Estonian riddles. Briefly, the following changes have taken place:

1) the "centre" (ordinary riddles) and "periphery" (trick questions, rebuses, etc.) of the genre have changed places in respect to their functionality and productivity: what used to be a periphery, flourishes, whereas the "ordinary" riddles are falling into oblivion;

2) the weight of trivial material within the repertoire of the "ordinary" riddles has grown (resp. that of the rare material has decreased); the natural oral formation of new riddles is scarce; riddles are mostly learned from books;

3 ) on a purely textological level, there is an unusually high percentage of texts within these records that are clearly copied from books - nearly $60 \%$. 
(About the status of riddles in contemporary school folklore, see Krikmann 1995.)

\section{Proverbial and Other Phrases}

There are three names to be mentioned in the phraseological studies of post-war Estonia: Feliks Vakk, Agnia Reitsak and Asta Õim. Vakk's theoretical field of interest embraced the etymology and genesis of phraseological units, relations of borrowing, as well as the essence of a set phrase (q.v. Vakk 1964; 1970; 1979; 1984). Reitsak, by education a Russian philologist, has published primarily works on the Estonian-Russian phraseological relations (Reitsak 1969; 1975). Õim's greatest publication so far has been the dictionary of Estonian phraseology (Õim 1993).

Non-proverbial phrases have been practically excluded from the work of the research group of paremiology so far. Ingrid Sarv was engaged into the Baltic-Finnic proverb project just a few months before she defended her dissertation on the sub-classes and functions of Estonian phrases (Sarv 1964b), which was meant to be the first part of a lengthy series of studies, giving a detailed treatment of expressions based on repetition, traditional pairs of words and popular comparisons. She had earlier published a special study of the latter (Sarv 1960), as well as shorter writings on turns of speech. Her work at proverbs interrupted this direction in her research for decades.

The technical term for phrases in the Estonian folklore studies - kõnekäänud - is very wide and vague, marking in principle all traditional non-paremic expressions, while their limits and relations "up" (e.g. with proverbs, repartees, comical mini-narratives, etc.) and "down" (with phraseological units, linguistic metaphors) have never been studied. This is by no means a genetic characteristic of the Estonians - for instance, it is not clear which phrases are "proverbial" and which are not in the English writings; or consider, for example, Fr. Seiler's (1922:11 ff., 231 ff.) and O. Moll's (1968) interpretations of the term Sprichwörtliche Redensart that differ from each other cardinally.

The heaps of material stored in the Estonian Folklore Archives and called the files of kõnekäänud, which in principle should include copies of all the recordings of non-paremic expressions recorded in the Estonian language and folklore collections, number perhaps all but 200,000 texts. At present, the bulk of it has been divided simply according to the place of origin (parish) of the recordings, there is no typological system whatsoever and to try to find the material after any non-geographical characteristic is extremely painstaking. However, within the limits of a project granted by the Estonian Science Foundation, work was started in July 1994 to eliminate the chaos and to arrange the files of phrases typologically in a similar manner as that of the proverbs and riddles. The team is made up of A. Krikmann and three senior students of the Department of Estonian Philology at Tartu University. The project has two more default aims: first, to pave the road for a scientific publication of Estonian phrases; second, to launch a natural rotation in the research group of paremiology, the staff of which is hopelessly aged, and to guarantee a succession of Estonian paremiological studies and to revive the phraseological studies in Estonia that have practically stopped after A. Reitsak and F. Vakk passed away (1974 and 1987).

Early folklore, incl. the tradition of sayings, has been decaying more and more rapidly within the past decades. It has been substituted by a brand new (as regards its sources, principles of creation as well as typological build) layer of rhetorics which contains elements of the old but is mainly fed by mass communication, films and literature, differs considerably in different social groups, is very topical and short-lived and adjacent to slang. The usage of these "catchwords", "quips" (paroolid, killud) or whatever you call them is flourishing rampantly (particularly among the younger generation), but the material collected by folklorists and linguists is too scanty to give a general survey, let alone to study them in depth. Mai Loog's dictionary of slang (Loog 1991) is a 
praiseworthy source to get acquainted with the material, but not very representative temporally and socially. In autumn 1994 the folklore institutions planned to organize an extensive "quip-picking" action at the higher schools of Tartu and Tallinn, in order to eliminate this "black hole" in our archives, and also to win young contributors who would continue fieldwork in this subject and ensure the continuity of observation of the contemporary developments in folklore.

\section{Cauda Festiva}

Juri Lotman, one of the most outstanding citizens of Tartu has mentioned that one's own culture seems to lack any specific traits, and no doubt it is so. Therefore we, insiders, did not try to point out what has been more important and what less important in the first 30 years of the research group of paremiology, we rather tried to speak about some objective facts in our CV which could be of some informative value to the paremiological brotherhood.

There are two things, however, which seem to be undeniable: that the Estonian paremiological research does exist and that it owes thanks for its existence to Matti Kuusi. What would parents do if children came to them saying, "Father, we thank you for having sired us! Mother, we thank you for having given birth to us! Parents, we thank you for having fed us and brought us up!" False parents would think, "What on earth would they want from us after such an introduction?" Truer ones would be moved to tears. Especially true ones would say, "Do not thank us, have your own babies, feed them and clothe them and bring them up - then your obligation will be paid off". We have known Matti Kuusi for 30 years and we know that he is an especially true one.

\section{References}

\section{Abbreviations}

EP $=$ Eesti vanasõnad (Estonian Proverbs). I-V:2. Toim. A. Krikmann, I. Sarv. Koost. A. Hussar, A. Krikmann, E. Normann, V. Pino, I. Sarv, R. Saukas. Tallinn, 1980-1988.

PS = Proverbia Septentrionalia. 900 Balto-Finnic Proverb Types with Russian, Baltic, German and Scandinavian Parallels. By Matti Kuusi in co-operation with Marje Joalaid, Arvo Krikmann, Pentti Leino, Elsa Kokare, Kari Laukkanen, Vaina Mälk, Ingrid Sarv. FF Communications no. 236. Helsinki, 1985.

\section{Manuscripts}

Clare, Johann Christoph 1730s. /4 variants of the (South-)Estonian-German vocabulary (stored in the Estonian Literary Museum in Tartu):/ (1) Vocabularium Esthonico-Teutonicum et TeutonicoEsthonicum Dorpatensi dialecto accommodatum curante Joanne Christophoro Clare, Pastore Odenpaeensi; (2) Cellarius Esthonico Teutonicus Dorpatensi Dialecto acom/m/odatus oder Esthnisch-Deutsches Wörter-Buch; (3) Cellarius Esthonico-Germanicus oder Wörter-Buch der Ehstnischen Sprache /---/; (4) Vocabularium Esthonico Teutonicum et Teutonico Esthonicum Dorpatensi Dialecto accommodatum.

Heller, Johann Friedrich 1830s? Estnisch-Deutsches Wörterbuch /stored in the Estonian Literary Museum in Tartu/.

Vestring, Salomo Heinrich 1720s? Lexicon Esthonico Germanicum /stored in the Estonian Literary Museum in Tartu/. 


\section{Publications}

Abrahams, Roger 1967. On Proverb Collecting and Proverb Collections. Proverbium 8, pp. 181184.

Arvelius, Friedrich Gustav 1782 and 1787. Üks Kaunis Jutto- ja Öppetusse-Ramat. /Part 1 - 1782; part 2 - 1787./ Tallinn.

Eisen, Matthias Johann 1890. Eesti rahva mõistatused. Tartu.

Eisen, Matthias Johann 1913 (a). Meie vanahõbe. Sarjatäis Eesti rahva endist tarkust,

kõnekäänusid ja ütlusi. Tartu.

Eisen, Matthias Johann 1913 (b). Eesti mõistatused. Tartu.

Eisen, Matthias Johann 1914 (a). Eesti vanadsõnad. Tartu.

Eisen, Matthias Johann 1914 (b). Mõista, mõista, mis see on. Mõistatused, keerulised küsimused ja mõistatuse-jutud. Tartu.

Eisen, Matthias Johann 1929. Eesti vanasõnad. Tartu.

Göseken, Heinrich 1660. Manuductio ad Linguam Oesthonicam. Anführung zur Öhstnischen

Sprache /---/. Reval.

Grigas, Kazys 1987. Patarliå paralel_s. Vilnius.

Grzybek, Peter and Chlosta, Christoph 1993. Grundlagen der empirischen Sprichwortforschung.

Proverbium. Yearbook of International Proverb Scholarship 10, pp. 89-128.

Gutslaff, Johann 1648. Observationes Grammaticae circa linguam Esthonicam /---/. Dorpat.

Helle, Anton Thor 1732. Kurtzgefaßte Anweisung zur Ehstnischen Sprache /---/. Halle.

Hornung, Johann 1693. Grammatica Esthonica /---/. Riga.

Hupel, August Wilhelm 1780. Ehstnische Sprachlehre für beide Hauptdialekte /---/. Riga u.

Leipzig.

Hupel, August Wilhelm 1818. Ehstnische Sprachlehre für die beyden Hauptdialekte /---/. Zweyte

durchgängig verbeßerte und wermehrte Auflage. Mitau.

Hussar, Anne, Krikmann, Arvo and Sarv, Ingrid 1984. Vanasõnaraamat. Tallinn.

Kaukamaa, L. I. and Valonen, Niilo 1939. Satakunnan sananparsia. Porvoo.

Kokare, Elza 1967. Divu tautu dzives gudriba. Riga.

Kokare, Elza 1980. Latviesu un lietuviesu sakamvardu paraleles. Riga.

Kokare, Elza 1988. Latviesu un vacu sakamvardu paraleles. Riga.

Koskimies, Aukusti Valdemar 1906. Kokoelma Suomen kansan sananlaskuja. Helsinki.

Krikmann, Arvo 1974. Some Difficulties Arising at Semantic Classifying of Proverbs. Proverbium 23, pp. 865-879.

Krikmann, Arvo 1974/1984. On Denotative Indefiniteness of Proverbs. Preprint KKI-1. Tallinn. (Reprinted in: Proverbium. Yearbook of International Proverb Scholarship 1, pp. 58-85.)

Krikmann, Arvo 1974/1985. Some Additional Aspects of Semantic Indefiniteness of Proverbs.

Preprint KKI-2. Tallinn. (Reprinted in: Proverbium. Yearbook of International Proverb Scholarship 2, pp. 58-85.)

Krikmann, Arvo 1975. K problematike issledovanija soderzhanija i mirovozzrenija poslovic.

Avtoreferat dissertacii na soiskanie uchenoj stepeni kandidata filologicheskih nauk. Tallinn.

Krikmann, Arvo 1978 (a). Folkloristliku kartograafia töömailt. Eskiis hobuse ja härja geograafiast.

Keel ja Kirjandus, no. 11, pp. 665-674.

Krikmann, Arvo 1978 (b). Nekotorye aspekty semanticheskoj neopredelennosti poslovicy.

Paremiologicheskij sbornik. Poslovica, zagadka (struktura, smysl, tekst). Ed. by G. L. Permjakov, pp. 82-104. Moskva.

Krikmann, Arvo 1979. Some Aspects of Proverb Distribution. Symposium on Mathematical

Processing of Cartographic Data, Tallinn, December 18-19, 1979, pp. 28-44. Tallinn. 
Krikmann, Arvo 1980. Towards the Typology of Estonian Folklore Regions. Preprint KKI-16. Tallinn.

Krikmann, Arvo 1984. "Vanasõnaraamatu" sisulisest süsteemist. In: Hussar, Krikmann and Sarv 1984, pp. 565-580.

Krikmann, Arvo 1984/1987. 1001 Frage zur logischen Struktur der Sprichwörter. Semiotische Studien zum Sprichwort. Simple Forms Reconsidered I. Special Issue of Kodikas/Code - Ars Semeiotica. An International Journal of Semiotics. Vol. 7, no. 3/4, pp. 387-408. (Reprinted in Estonian: 1001 küsimust vanasõnade loogilise struktuuri kohta. Dialoogi mudelid ja eesti keel. TRÜ toimetised, no. 795. Tartu, pp. 120-150.)

Krikmann, Arvo 1984/1988. Opyt ob'jasnenija nekotoryh semanticheskih mehanizmov poslovicy. Paremiologicheskie issledovanija. Sbornik statej. Ed. by G. L. Permjakov, pp. 149-178. Moskva. (Reprinted in French: "Mécanismes sémantiques"quot; de l'énoncé proverbial. Tel grain tel pain. Poétique de la sagesse populaire. Sous la rédaction de Grigori Permiakov, pp. 82-113. Moscou.) Krikmann, Arvo 1985/1987. Some Statistics on Balto-Finnic Proverbs. Preprint KKI-36. Tallinn. (Reprinted in Estonian: Statistilisi vaatlusi populaaarsemaist läänemeresoome vanasõnadest. Rahvaluulest. Eesti NSV TA Emakeele Seltsi toimetised, no. 21, pp. 76-125. Tallinn.) Krikmann, Arvo 1986 (a). Paremiologicheskie eksperimenty G. L. Permjakova. Preprint KKI-40. Tallinn.

Krikmann, Arvo 1986 (b). Fraseoloogiline aines eesti vanimais grammatikates ja sõnastikes.

Tallinn.

Krikmann, Arvo 1992 (a). Fraseoloogilisi elemente Georg Mülleri jutlustes. Keel ja Kirjandus, no. 11, pp. $144-150$.

Krikmann, Arvo 1992 (b). Härjamari, vähirasv. Zoohübriididest ja -absurdidest paröömikas. Keel ja Kirjandus, no. 11, pp. 667-682.

Krikmann, Arvo 1994. Suure Ahela Metafoor - võti või muukraud vanasõnade semantikasse? Keel ja Kirjandus, no. 2, pp. 93-98.

Krikmann, Arvo 1995. Lipitud-lapitud "Kommunaari" king. Mõistatused tänapäeva koolipärimuses. Lipitud-lapitud. Tänapäeva folkloorist, pp. 33-58. Tartu.

Kuusi, Matti 1953. Vanhan kansan sananlaskuviisaus. Suomalaisia elämänohjeita, kansanaforismeja, lentäviä lauseita ja kokkapuheita vuosilta 1544-1826. Porvoo.

Kuusi, Matti 1954. Sananlaskut ja puheenparret. Helsinki.

Kuusi, Matti 1970. How Can a Type-Index of International Proverbs Be Outlined? An Experiment and Five Questions. Proverbium 15, pp. 57(473)- 60(476).

Kuusi, Matti 1972. Towards an International Type-System of Proverbs. FF Communications, no. 211. (Reprinted in: Proverbium 19, pp. 699-736.)

Kuusi, Matti 1981. Rahvusvahelise parömioloogia tippsaavutus. ("Eesti vanasõnad I. /---/. Tallinn, 1980.") Keel ja Kirjandus, no. 4, pp. 240-242.

Kuusi, Matti 1990. "Eesti vanasõnad I - V . /---/. Tallinn, 1980-1988." Proverbium. Yearbook of International Proverb Scholarship 7, pp. 269-272.

Kuusi, Matti and Lauhakangas, Outi 1993. Maailman sananlaskuviisaus. Porvoo - Helsinki - Juva. Laiho, Lauri 1941. Etelä-Karjalan sananparsia. Porvoo.

Laugaste, Eduard 1955. Rahvaluulelisi aineid S. H. Vestringi eesti-saksa sõnaraamatu käsikirjas. TRÜ toimetised, no. 38. Ajaloo-Keeleteaduskonna töid, pp. 167-180. Tallinn.

Laukkanen, Kari 1982. Ein parömiologisches Monument. ("Eesti vanasõnad I. /---/ Tallinn, 1980.") Finnisch-ugrische Forschungen. Vol. XLIV, pp. 247-256.

Laukkanen, Kari and Hakamies, Pekka 1978. Sananlaskut. Vaasa.

Loog, Mai 1991. Esimene eesti slängi sõnaraamat. Tallinn.

Luukko, Armas 1938. Etelä-Pohjanmaan sananparsia. Porvoo. 
Mälk, Vaina 1977. Vadja vanasõnad eesti, soome, karjala ja vene vastetega. Tallinn.

Mälk, Vaina et al. 1981. Liivi vanasõnad eesti, vadja ja läti vastetega. I-II. Tallinn.

Mälk, Vaina et al. 1991. Vepsa vanasõnad eesti, vadja, liivi, karjala ja vene vastetega. I-II. Tallinn.

Mieder, Wolfgang 1986. "Proverbia Septentrionalia. 900 Balto-Finnic Proverb Types /---/. FF

Communications, no. 236. Helsinki, 1985." Proverbium. Yearbook of International Proverb

Scholarship 3, pp. 325-334.

Miettinen, Liisa and Leino, Pentti 1971. Karjalaisia sananpolvia. Helsinki.

Moll, Otto 1958. Sprichwörterbibliographie. Frankfurt.

Moll, Otto 1968. Parömiologische Fachausdrücke und Definitionen. Proverbium 10, pp. 249-250.

Nirvi, R. E. and Hakulinen, Lauri 1948. Suomen kansan sananparsikirja. Porvoo - Helsinki.

Normann, Erna 1955. Valimik eesti vanasõnu. Tallinn.

Normann, Erna 1959. Vanasõnad J. Ch. Clare eesti-saksa sõnaraamatus. Emakeele Seltsi

aastaraamat $\mathrm{V}$, pp. 18-40, Tallinn.

Normann, Erna 1961. M.J. Eiseni mõistatuste ja vanasõnade trükiväljaanded. Paar sammukest eesti kirjanduse ja rahvaluule uurimise teed. Uurimusi ja materjale II, pp. 422-434. Tartu.

Õ im, Asta 1993. Fraseoloogiasõnaraamat. Tallinn.

Permjakov, Grigori 1971. Paremiologicheskij eksperiment. Materialy dlja paremiologicheskogo minimuma. Moskva.

Permjakov, Grigori 1988. Osnovy strukturnoj paremiologii. Moskva.

Posti, Lauri 1936. Varsinais-Suomen sananparsia. Porvoo.

Reiman, Villem 1891. Neununddreißig Estnische Predigten von Georg Müller aus den Jahren 1600-1606. Verhandlungen der gelehrten Estnischen Gesellschaft zu Dorpat. Fünfzehnter Band.

Dorpat.

Reitsak, Agnia 1969. Valimik vene vanasõnu eesti vastetega. Tallinn.

Reitsak, Agnia 1975. Valimik vene fraseologisme eesti vastetega. Tallinn.

Rosenplänter, Johann Heinrich (ed.) 1813-1832. Beiträge zur genauern Kenntniss der estnischen Sprache. /I-XX./ Pernau.

Saarto, Maila 1945. Uudenmaan sananparsia. Porvoo.

Saleman, Georg 1655. Etzliche Gebete Für die Ehstnische Gemeine in Liffland /---/. Reval.

Salo, Vello 1980. Memento monumenti! ("Eesti vanasõnad I. /---/ Tallinn, 1980.") Aja Kiri, no. 6, pp. 6-12.

Sarv, Ingrid 1960. Rahvapärane võrdlus kui kõnekäänu eriliik. TRÜ toimetised, no. 94. Tartu.

Sarv, Ingrid 1964 (a). Eesti vanasõnade ja kõnekäändude publitseerimisest ning uurimisest. Eesti rahvaluulest, pp. 97-125. Tallinn.

Sarv, Ingrid 1964 (b). O podvidah I funkcijah estonskih pogovorok I. Avtoreferat dissertacii na soiskanie uchenoj stepeni kandidata filologicheskih nauk. Tartu.

Seiler, Friedrich 1922. Deutsche Sprichwörterkunde. München.

Stahl, Heinrich 1632-1638. Hand- vnd Haußbuch für das Fürstenthumb Ehsten In Liffland. /I-IV./

Riga - Reval.

Stahl, Heinrich 1637. Anführung zu der Ehstnischen Sprach /---/. Revall.

Stahl, Heinrich 1641 and 1649. Leyen Spiegel /---/. Revall.

Tóthné-Litovkina 1988? Analiz jazyka vengerskih poslovic (russkie ekvivalenty vengerskim poslovicam). Proverbium Paratum 4 (1983-1989).

Vaasan Jaakkoo 1920. Eteläpohjalaisia sananparsia. Vaasa.

Vakk, Feliks 1964. O somaticheskoj frazeologii v sovremennom estonskom literaturnom jazyke.

Avtoreferat dissertacii na soiskanie uchenoj stepeni kandidata filologicheskih nauk. Tallinn.

Vakk, Feliks 1970. Suured ninad murdsid päid (Pea ja selle osad rahvalike ütluste peeglis).

Tallinn. 
Vakk, Feliks 1979. Die semantische Übertragung und die Wege der Entstehung der estnischen Phraseologie. Explanationes et tractationes Fenno-Ugricae in honorem Hans Fromm, pp. 405-416. München.

Vakk, Feliks 1984. Miks just nõnda? Peotäis tekkelugusid ja undistavaid lühimatku eesti fraseoloogia radadelt. Tallinn.

Vesikansa, Jouko 1941. Hämeen sananparsia. Porvoo.

Wiedemann, Ferdinand Johann 1869. Ehstnisch-Deutsches Wörterbuch. St. Petersburg.

Wiedemann, Ferdinand Johann 1876. Aus dem inneren und äusseren Leben der Ehsten. St.

Petersburg.

Willmann, Friedrich Wilhelm 1782. Juttud ja Teggud/---/. Tallinn. 